\title{
ISLANDERS, PROTESTANT MISSIONARIES, AND TRADITIONS REGARDING THE PAST IN NINETEENTH-CENTURY POLYNESIA*
}

\author{
TOM SM I TH \\ University of Cambridge
}

\begin{abstract}
A B ST R ACT. In this article, I consider Polynesian genealogies, which took the form of epic poems composed and recited by specialist genealogists, and were handed down orally through generations of Polynesians. Some were written down in the nineteenth century, reaching an English-speaking audience through a number of works largely neglected by historians. In recent years, some anthropologists have downplayed the possibility of learning anything significant about Polynesian thought through English-language sources, but I show that there is still fresh historical insight to be gained in demonstrating how genealogies came to interact with the traditions of outsiders in the nineteenth century. While not seeking to make any absolute claims about genealogy itself, I analyse a wide body of English-language literature, relating chiefly to Hawai ' $i$, and see emerging from it suggestions of a dynamic Polynesian oral tradition responsive to political, social, and religious upheaval. Tellingly, Protestant missionaries arriving in the islands set their own view of history against this supposedly irrelevant tradition, and in doing so disagreed with late nineteenth-century European and American colonists and scholars who sought to emphasize the historical significance of genealogy. Thus, Western ideas about history found themselves confounded and fragmented by Polynesian traditions.
\end{abstract}

'Genealogies are the Hawaiian concept of time, and they order the space around us.' Prominent twentieth-century scholar of Hawaiian genealogy Kame"eleihiwa here indicates the importance of genealogies for Polynesians. They were ubiquitous in oral tradition throughout Polynesia, sometimes appearing simply as lists of forebears' names, though often tied to cosmogonic

Trinity Hall, Cambridge, CB2 ITJ tds33@cam.ac.uk

* Many thanks to Sujit Sivasundaram, who supervised the thesis upon which this article is based and was a source of great insight and encouragement. Thanks also to those who offered helpful comments at various stages, notably David Maxwell, Maia Nuku, Kate Stevens, Seth Archer, Lottie Field, the anonymous peer reviewers, and participants in both the Cambridge World History Workshop and Dr Sivasundaram's graduate reading group.

${ }^{1}$ Qu. N. K. Silva, Aloha betrayed: native Hawaiian resistance to American colonialism (Durham, NC, 2004), p. 93 . 
narratives through epic poems, which specially appointed genealogists composed, committed to memory, and recited. The most complete extant example of a genealogical chant available to the English-speaking scholar is American ethnographer Martha Beckwith's $195^{1}$ translation of the Hawaiian Kumulipo, recorded in print as an expression of resistance to American colonialism in the 188 os. This traces the Hawaiian story from the beginnings of the earth, and includes over 1 ,ooo lines detailing genealogical descent. ${ }^{2}$ Further fragments of translated genealogical narratives from all over Polynesia are found in a diverse range of works: those of missionaries and others who drew upon their notes; those of non-missionary observers like Hawai'i-based American judge Abraham Fornander and ethnologist John Fraser; and more rarely those of genealogists converted to Christianity whose works were translated, notably Hawaiian scholars David Malo and Samuel Kamakau. ${ }^{3}$

The nineteenth century was a period in which the Pacific Ocean was prominent in the minds of Europeans and Americans. The writings of Captain Cook and other late eighteenth-century travellers inspired a range of responses by representing Polynesian islands simultaneously as spaces of unparalleled beauty and sexual freedom, and as untapped sites for trade and scientific observation. 4 Desire spilled over into colonial control in the mid-nineteenth century: the treaty of Waitangi brought New Zealand under British sovereignty in 1840; Tahiti became a French protectorate in 1842 and a colony in 1880 ; Samoa was the subject of German and American competition and colonization towards the end of the century; Hawai' $i$ was annexed by the United States in 1898 following a gradual erosion of sovereignty; and the Cook Islands and Tonga fell under British protection in 1888 and 1900 respectively. It was thus a century of rapid change in the region, in which islanders were increasingly aware of attempts by outsiders to dominate, first through trade, exploration, and mission, and latterly through formal colonialism.

Polynesia became a testing ground for intensive Protestant mission work when the London Missionary Society (LMS), responding to travellers'

${ }^{2}$ M.W. Beckwith, trans. and ed., The Kumulipo: a Hawaiian creation chant (Chicago, IL, $195^{1)}$.

${ }_{3}$ For missionary records, see W.W. Gill, Myths and songs from the South Pacific (London, 1876); G. Turner, Samoa: a hundred years ago and long before, together with notes on the cults and customs of twenty-three other islands in the Pacific (London, 1884); J. B. Stair, Old Samoa, or flotsam and jetsam from the Pacific Ocean (London, 1897); T. Henry, Ancient Tahiti: based on material recorded by J. M. Orsmond (Honolulu, HI, 1928); for non-missionary observers' work, see A. Fornander, An account of the Polynesian race: its origins and migrations and the ancient history of the Hawaiian people to the times of Kamehameha I (3 vols., Rutland, VT, 1969), I; J. Fraser, 'The Samoan story of creation - a "tala", Journal of the Polynesian Society, 1 (1892), pp. 164-89; for indigenous scholars' work see D. Malo, Hawaiian antiquities (Moolelo Hawaii), trans. N. B. Emerson (Honolulu, HI, 1951); S. M. Kamakau, Tales and traditions of the people of old (No moolelo a ka poe kahiko), trans. M. K. Pukui, ed. D. B. Barrère (Honolulu, HI, 1991).

4 A. Salmond, Aphrodite's island: the European discovery of Tahiti (Auckland, 2009), p. 20; B. Smith, European vision and the South Pacific, I769-I850: a study in the history of art and ideas (Oxford, 1960), p. 91. 
descriptions of an indolent South Pacific, sent the missionary ship Duff to the Society Islands in 1797.5 The subsequent encounter served as a site for the formation of ideas about race, knowledge, and empire, and provided a springboard for later work in the Cook Islands and Samoa by LMS workers and their converts. ${ }^{6}$ The LMS were followed into Polynesia by the Church Missionary Society (CMS) who worked in New Zealand from 1814, the American Board of Commissioners for Foreign Missions (ABCFM) who went to Hawai' $i$ in 1820 , and Wesleyan Methodists stationed in New Zealand from 1823 , Tonga from 1826 (after previous abortive attempts), and Samoa from 1835 .

Missionaries were the first outsiders to engage intensively with the substantial and perplexing body of oral tradition constituted by Polynesian genealogies. On the one hand, these accounts appeared to represent a view of the past much like missionaries' own, of divine creation and subsequent reproduction of generation after generation. However, versions of the past were also numerous and contradictory, and their ultimate refusal to adhere to outsiders' chronological sensibilities played into missionary assumptions that Polynesians lacked appropriate concern for time: J. M. Orsmond of the LMS lamented the 'treacherous memory' of Polynesians, believing them to have obfuscated historical truth in their reliance on oral transmission. 7 Polynesia is a particularly good site for considering how such well-established yet untested evangelical assumptions were carried to the mission field, and how perceptions were reshaped through a formative instance of a new type of cultural encounter.

There are clear problems associated with studying oral tradition. Collectors frequently commented that islanders resented being robbed of their 'only treasure', or feared offending their gods, and as such modified narratives when sharing them with outsiders. ${ }^{8}$ Katherine Luomala meanwhile warns that genealogies went through many layers of filtration before being committed to print. 9

5 S. Sivasundaram, Nature and the godly empire: science and evangelical mission in the Pacific, I795-I850 (Cambridge, 2005), pp. 1-2; N. Thomas, Islanders: the Pacific in an age of empire (New Haven, CT, 2010), p. 26.

${ }^{6} \mathrm{~S}$. Thorne, Congregational missions and the making of an imperial culture in nineteenth-century England (Stanford, CA, 1999), pp. 6-7; A. Johnston, Missionary writing and empire, I 800-I860 (Cambridge, 2003), p. 2; Sivasundaram, Nature, pp. 3-4; D. Wetherell, 'Pioneers and patriarchs: Samoans in a nonconformist mission district in Papua, 1890-1917', Journal of Pacific History, 15 (1980), pp. 130-54, at p. 130; J. Barker, 'Where the missionary frontier ran ahead of empire', in N. Etherington, ed., Missions and empire (Oxford, 2005), pp. 93-4; P. Brock, 'New Christians as evangelists', in Etherington, ed., Missions and empire, p. 133; R. Lange, Island ministers: indigenous leadership in nineteenth-century Pacific islands (Christchurch and Canberra, 2005), pp. 39-43; M. K. Matsuda, Pacific worlds: a history of seas, peoples, and cultures (Cambridge, 2012), p. 144 .

7 Henry, Ancient Tahiti, p. i.

${ }^{8}$ Beckwith, trans. and ed., Kumulipo, p. 4o; Henry, Ancient Tahiti, p. 1og; Fraser, 'Samoan story', pp. $165^{-6 .}$.

9 K. Luomala, 'Documentary research in Polynesian mythology', Journal of the Polynesian Society, 49 (1940), pp. 175-96, at p. 176 ; Henry, Ancient Tahiti. 
Orsmond's collection of Tahitian accounts, for example, was only published in 1928 after his manuscripts had been interpreted by his granddaughter Teuira Henry, whose writings were then edited themselves. We know in addition that a great amount of transcribed material was lost, notably the collections of LMS missionary Charles Barff, and that Christian transcribers, unwittingly or deliberately, suppressed traditional imagery; Orsmond, for example, omitted a section depicting copulation between deities in his version of a Tahitian chant. ${ }^{10}$

Indeed, anthropologists have recently questioned whether anything significant can be learned about Polynesian thought through sources written down in English. Marvin Puakea Nogelmeier characterizes the over-reliance of scholars on a small corpus of translated sources, decontextualized and reordered beyond recognition, as part of a pernicious Orientalizing attempt to create an English-language canon for studying the Hawaiian past. This presents a 'monorhetorical' story, 'linear... and intolerant of varying explanations', at odds with Polynesians' own 'polyrhetorical' understandings which are better elucidated by, for example, a substantial yet ignored body of Hawaiian-language newspapers from between 1834 and $1948 .{ }^{11}$ Brandy Nālani McDougall has similarly critiqued Beckwith's Kumulipo as an example of 'colonial silencing'. ${ }^{12}$ She says that in order to appreciate the significance of the Kumulipo, we must acknowledge the importance of kaona ('hidden meaning'), which demands 'a complex interactive and dynamic relationship between the composer and the audience', and 'shared cultural, historical, and geographical knowledge'. ${ }^{13}$

Nogelmeier's and McDougall's contributions valuably expose the power differentials which have coloured considerations of genealogy, and indeed much work is to be done to recover the Polynesian voice. In this article, however, I return to English-language translations and interpretations of nineteenthcentury genealogies. Though I appreciate that no absolute claims about Polynesian conceptions of the past can be made through such works, they have only rarely been used by historians, and there is much to be gained from considering how genealogies interacted with outsiders. I believe that we might use these writings to shed light on how the dynamism of Polynesian thought often confounded and fragmented European and American epistemology and undermined its claims to 'monorhetorical' understanding.

${ }^{10}$ N. Gunson, 'Understanding Polynesian traditional history', Journal of Pacific History, 28 (1993), pp. 139-58, at pp. 140, 142; K. P. Emory, 'The Tahitian account of creation by Mare', Journal of the Polynesian Society, 47 (1938), pp. 45-63, at p. 53.

${ }^{11}$ M. P. Nogelmeier, Mai pa'a $i$ ka leo: historical voice in Hawaiian primary materials, looking forward and listening back (Honolulu, HI, 2010), pp. xi-xiv, 3-12, 17-26, 46, 59, 157 .

${ }^{12}$ B. N. McDougall, 'Genealogy, colonial entitlement, and the politics of translation of the Kumulipo', paper presented at Oceanic archives and transnational American studies, conference at the University of Hong Kong, June 2012.

13 B. N. McDougall, 'Putting feathers on our words: kaona as a decolonial aesthetic practice in Hawaiian literature', Decolonization: Indigeneity, Education $\mathcal{E}$ Society, 3 (2014), pp. 1-22, at p. 3 . 
In the first and second sections of the article, I focus primarily on Hawai' $i$, where Beckwith's Kumulipo provides an interesting basis for discussion. I seek to show how, by considering English-language sources and cross-referencing them with recent anthropological study, we might draw out some of the creative tension between nineteenth-century indigenous and outsider understandings of the past, which were formulated against a backdrop of political, social, and religious upheaval. These were constructed in numerous ways, and there are suggestive commonalities and points of divergence to be explored across traditions. In recognizing this, we move beyond debates about whether or not genealogies can be used to reconstruct history or chronology, which have characterized much previous analysis. ${ }^{14}$ Genealogy should not be equated with chronology, and we should not assume that Polynesians were trying to create a narrative acceptable to Western historiography, and failed because of their oral tradition. Rather, we can infer even from English-language sources not only that Polynesians attached importance to the past as a key source of social stability, but also that their cosmology was responsive to the rapid changes in their region, incorporating Christian ideas which altered islanders' perceptions of time, even when missionaries did not perceive them to have undergone conversion. As such, genealogies embodied neither straightforward Polynesian agency, nor the imposition of Christianity, but a fluid and evolving conception of the past, and each recorded genealogy comprised its own combination of pan-Polynesian imagery, specific tribal motifs, and Christian influences.

By better understanding how genealogies were characterized in English-language literature, we can go on to make fresh claims about how outsiders struggled to come to terms with dynamism within Polynesian thought, and thus how Western discourse about time was destabilized when confronted with genealogies. Specifically, despite ostensibly sharing a culture of temporality, missionaries in some ways disagreed with non-missionaries such as Fornander and Fraser as to the place that genealogical accounts should occupy within attempts to reconstruct Polynesian history. As such, I emphasize that 'history' is not the 'correct' way of recording the past, but a construct which in itself could prove 'polyrhetorical'.

Although the bulk of my evidence is drawn from Hawai'i, I bring in other Polynesian island groups throughout for comparative context, especially the Society Islands and Samoa. This way, I hint at the wider applicability of my argument, which I believe speaks to existing literature on Polynesian genealogy, particularly rich in the case of New Zealand thanks to the work of D. R. Simmons, M. P. K. Sorrenson, and Margaret Orbell among others. Such studies effectively and necessarily critiqued long-accepted European models, pioneered by

${ }^{14}$ J. B. W. Roberton, 'Genealogies as a basis for Maori chronology', Journal of the Polynesian Society, 65 (1956), pp. $45^{-5}$, at p. 49; R. Piddington, 'A note on the validity and significance of Polynesian traditions', Journal of the Polynesian Society, 65 (1956), pp. 200-3. 
ethnologist S. Percy Smith, which failed to appreciate the significance of 'myth' in genealogy and represented tradition as akin to 'history' in a manner so pernicious that even Maori themselves came to accept such interpretations. ${ }^{15}$ What I add is a more nuanced discussion of the ways in which genealogical traditions, in the context of cultural encounter, provided the platform for a multi-directional creative process which affected European and American views of the past as much as Polynesian conceptions.

Ultimately, I move beyond both Marshall Sahlins's structuralist view which suggests that islanders received Europeans in terms of their existing cosmology and Gananath Obeyesekere's argument that Polynesians responded solely to European 'mythmaking', by demonstrating that neither islanders' nor outsiders' thought can be treated monolithically. ${ }^{16}$ Global historians and historical anthropologists should recognize that cultural encounter does not simply entail bipolarized worldviews, but holds inherent creative potential as indigenous discourses adapt in ways which in turn shine light through the fissures in outsiders' epistemologies.

\section{I}

Superficially, a clear sense of the importance of chronology to Polynesians was conveyed by genealogies. They provided legitimacy by linking individuals with chiefly and priestly lines, professional groups, and families with certain gods, and families or societies with land. Thus, American journalist and historian Henry Adams, writing about Tahiti in 1901, noted that:

Perhaps the most decisive part of every head-chief's influence was his family connection... On this foundation genealogy grew into a science... which could fairly claim a rank with the intellectual work of Europe and Asia...Chiefs might wander off to distant islands and be lost for generations, but if their descendants came back, and if he could prove his right to the seat in a family Marae [temple], he was admitted to all the privileges and property which belonged to him by inheritance. ${ }^{17}$

The preservation of the prestige of a particular line was of utmost importance and, as such, genealogists conducted painstaking searches to find wives for

15 D. R. Simmons, The great New Zealand myth: a study of the discovery and origin traditions of the Maori (Wellington, 1976); M. P. K. Sorrenson, Maori origins and migrations: the genesis of some Pakeha myths and legends (Auckland, 1979); M. Orbell, Hawaiki: a new approach to Maori tradition (Christchurch, 1985).

16 M. Sahlins, How 'natives' think: about Captain Cook, for example (Chicago, IL, 1995), p. 4; G. Obeyesekere, 'British cannibals: contemplation of an event in the death and resurrection of James Cook, explorer', Critical Inquiry, 18 (1992), pp. 630-54, at pp. 643-7; G. Obeyesekere, The apotheosis of Captain Cook: European mythmaking in the Pacific (Princeton, NJ, 1992), p. 10.

${ }_{17}$ H. Adams, Memoirs of Arii Taimai E, Marama of Eimeo, Teriirere of Tooarai, Teriinui of Tahiti, Tauraatua I Amo (Paris, 1901 ), pp. 10, 17. 
chiefs of sufficiently strong genealogical stock. ${ }^{18}$ The ability to draw a straight line from the present to the past was a meaningful element of Polynesian thought, which piqued the interest of observers including Adams. McDougall identifies an ongoing preoccupation with continuity in the work of Hawaiian author John Dominis Holt, who wrote that 'we are links to the ancients; connected by inheritance to their mana [sacred prestige], their wisdom, their superb appreciation of what it is to be human'. ${ }^{19}$

Genealogies differed from Western histories, however, in that they intertwined stories of nature and the human past, seeing both as vital sources of legitimacy: the Kumulipo, according to Beckwith, connected a royal line not only to gods and ancestors 'but to the stars... and the plants and animals'. ${ }^{20}$ For Westerners, history was the story of mankind having superseded nature, hence why their accounts of the Polynesian past often treated the arrival of explorers such as Cook as the beginning of Polynesia's real history. ${ }^{21}$ Polynesians, on the other hand, did not separate their story from that of the natural world which they acknowledged as preceding them and continuing to sustain them. This inter-relation was emphasized through metaphors linking apparently separate species, and everything to the gods: Tahiti was a fish which swam away from the ancestral homeland of Havai' $i$; plants sprang from parts of the human body; and Samoan accounts reference battles between natural objects which ascertained nature's hierarchy. ${ }^{22}$ Moreover, the evolution of the earth from nothingness was achieved through breeding pairs of personified natural objects and subsequent 'growth', demonstrating the vitality and creativity of nature, and the unbroken line from past to present. ${ }^{23}$ Indeed, Holt recognizes the importance of 'respecting all things of the earth, including rocks and dirt as living things somehow through a cosmic connection to ourselves' ${ }^{24}$

This cosmogonic heritage linked the many islands of Polynesia to a shared past. Particular gods and culture heroes recurred in tales of the past from across vast swathes of the Pacific, while the cosmogonic imagery of a condition of nothingness followed by a 'chaotic period' was widely held. ${ }^{25}$ Tales varied in many respects, but the preservation of agreed-upon material suggested that Polynesians held a common concern to link themselves to a symbolic shared

${ }^{18}$ Malo, Hawaiian antiquities, p. 54 .

19 Qu. McDougall, 'Putting feathers on our words', p. 13.

${ }^{20}$ Beckwith, trans. and ed., Kumulipo, p. 7.

${ }^{21} \mathrm{~J}$. Williams, A narrative of missionary enterprises in the South Sea islands, with remarks upon the natural history of the islands, origin, languages, traditions, and usages of the inhabitants (London, 1837), pp. 3-4; S. Dibble, History of the Sandwich Islands (Lahainaluna, 1843), p. 31; Fornander, Account, II, pp. 158-200; Adams, Memoirs, pp. 2, 46 .

${ }^{22}$ Henry, Ancient Tahiti, pp. 420-1, 437; Turner, Samoa, pp. 7, $212-13$.

${ }^{23}$ Fraser, 'Samoan story', pp. 168-9, 179; Silva, Aloha betrayed, p. 93; Beckwith, trans. and ed., Kumulipo, p. 23.

${ }^{24}$ Qu. McDougall, 'Putting feathers on our words', p. 13.

${ }^{25}$ M. W. Beckwith, 'Polynesian mythology', Journal of the Polynesian Society, 49 (1940), pp. 17-36, at p. 23; Beckwith, trans. and ed., Kumulipo, p. 161. 
past from which point their various genealogies branched out. ${ }^{26}$ Such commonalities were noted by European and American analysts in the nineteenth century, and have been confirmed through further anthropological study: Niel Gunson shows how shared ideas of common ancestors and homelands in genealogies shed light on inter-island marriage patterns and family alliances throughout Polynesia's past. ${ }^{27}$ This does not mean that Gunson wishes to homogenize Polynesians, however; he also emphasizes the importance of bifurcation as a motif and of shifting alliances over time, which gave rise to many different traditions about the same figure, for instance the god Tangaloa. ${ }^{28}$

Indeed, specific narratives brought particular islands to prominence within the overarching tale of commonality. A Board of Genealogy of Hawaiian Chiefs was formed in 1882 at King Kalākaua's behest in order to 'gather, revise, correct and record' genealogies, accounts, and chants. ${ }^{29}$ Its 1884 report said:

In the genealogy and traditions of the Tahitian Group, the Samoan Group, and other Islands toward the south-west of the Hawaiian Archipelago, the origin of their ancestors does not date back any further than Wakea or go2nd generation from Lailai. Whereas the Hawaiian Genealogy antedates them all, which indicates that these Islands were the starting points of all migrations to the south-west. $3^{\circ}$

Here, though a shared past with other Polynesians was acknowledged, Hawaiian superiority was asserted through a suggestion of longevity in comparison with other island groups. This claim appears spurious according to other traditions or archaeological records, but the Board clearly deemed itself to have presented a strong case by appealing to genealogical legitimacy. The nationalization of traditional accounts is also apparent elsewhere: Gunson finds that autochthony in origin myths was of particular importance to Samoans and Tongans; indeed, in nineteenth-century Samoa, pride was apparently derived from the idea that the islands were siblings of the sun and moon. ${ }^{31}$

The Hawaiian Board's work must be placed in the context of resistance to American colonialism at the end of the nineteenth century. Genealogy both validated Kalākaua's contested claim to the throne against Queen Dowager Emma, and asserted the link between indigenous Hawaiians and their land, against America. $3^{2}$ The Board were, in many ways, keen to demonstrate 'modern' sensibilities to Hawai'i's would-be colonizers, eschewing 'prejudices and superstitions' in favour of 'scientific principles', and engaging with

\footnotetext{
${ }^{26}$ Henry, Ancient Tahiti, p. $4_{5}$.

27 N. Gunson, 'Great families of Polynesia: inter-island links and marriage patterns', Journal of Pacific History, 32 (1997), pp. 139-52, at pp. 139-40, 152.

28 Ibid., pp. 140, 144 .

29 Report of the board of genealogy of Hawaiian chiefs (1884), p. 3 .

$3^{\circ}$ Ibid., p. 20.

$3^{1}$ Gunson, 'Great families', p. 139; Fraser, 'Samoan story', p. 169.

$3^{2}$ Silva, Aloha betrayed, pp. 90-1, 120.
} 
cartography, deep sea sounding, and theories of migration. 33 Regarding the past, however, they took 'no other guide than that furnished by ancient folklore'.34

Adams, Henry, and LMS missionary John Davies all included genealogies without explanation in their accounts of Polynesian history, suggesting that they appreciated their especial importance in telling the Polynesian story, and the apparent chronological sensibility displayed. 35 However, further analysis reveals that genealogy and chronology were not the same thing. In translating the Kumulipo, Beckwith made use of three different Hawaiian informants, each of whom had very different interpretations of what it represented: one suggested that it was indeed an account of life on Earth from the beginning down to the succession of a new royal child; another believed it was metaphoric for the life of a chief from infancy to adulthood; and a third thought it represented the spread of Polynesian groups across the Pacific. $3^{6}$ In this, we see that the Kumulipo might simultaneously represent a multiplicity of temporal spans. Moreover, language drew together space and time ambiguously in a manner recently explored in detail by Hawaiian anthropologist Katrina-Ann Oliveira. 37 The Kumulipo was divided into sixteen sections called $w a-$ a word which can represent an interval in time or space - and Beckwith shows that unfathomable antiquity was sometimes represented spatially, as a cave or pit..$^{8}$ The prevalent concept of darkness may in itself refer to the darkness in memory of a remote time, rather than to an empty space. 39 As such, we begin to see more complexity emerging.

Even more importantly, variability in accounts pointed to a worldview in which lineages were manipulated. Nineteenth-century writers on Polynesian genealogies remarked upon their variability, but John Stokes, an early twentiethcentury scholar, demonstrated the full extent: the number of generations listed before 1900 varied from 30 to 154 in the genealogies he considered, while 'the cosmogonic and mythical human names are seldom to be found either in close agreement, or in such order as to establish their identity in the

33 Report, pp. 11-26; Silva, Aloha betrayed, p. 97.

34 Report, p. 14.

35 Henry, Ancient Tahiti, pp. 247, 268; Adams, Memoirs, pp. 32, 39, 43, 76, 87, 95, 113 ; J. Davies, The history of the Tahitian mission, I799-I830, ed. C. W. Newbury (Cambridge, $1961)$, p. 364 .

$3^{6}$ Beckwith, trans. and ed., Kumulipo, pp. 40-1, 57, 68, 75 .

37 K.-A. R. N. Oliveira, Ancestral places: understanding Kanaka geographies (Corvallis, OR, 2014), pp. $2-5$.

$3^{8}$ Beckwith, trans. and ed., Kumulipo, pp. $37,96$.

39 Ibid., p. 47. 
different genealogies'.$^{\circ}$ Variations occurred not only between different islands, but between accounts from the same island. $4^{1}$

Damon Salesa suggests that these discrepancies were the conscious result of a particular conception of time rather than the consequence of error:

Genealogy orients time towards ancestors and descendants, not to an external systematic or a disembodied calibration... Time was thus experienced and understood differently through different cultures of genealogy, and so with history and the past...All measures of past and future time... are by necessity symbolic. And as the relevant symbolic systems must not only address the past, but integrate it with the present, all descriptions of time are sensitive to change. $4^{2}$

While Western histories themselves allowed for a remaking of the past through selective accounts of European discovery and Christian conversion, contemporary Westerners believed the object of studying the past was to uncover historical 'truth', as Orsmond clearly demonstrated in his assumptions about Polynesian oral tradition. Polynesians instead appeared to suggest that though the legitimacy imbued by heritage was important, most important was one's ability to lay appropriate claim to that heritage. Malo stressed that the preservation of a chief's genealogies was contingent on good behaviour.43 Kamakau, meanwhile, claimed that a chief victorious in war 'attached himself to the chiefly genealogies, even though his father may have been of no great rank'.44 Given this, it is unsurprising that the recitation of genealogical chants became important on key ceremonial occasions, for instance the birth of a child of chiefly line, for the purpose of repeatedly asserting a prestigious lineage against competitors. 45 Ultimately, says Kame'eleihiwa, Polynesians simply sought 'the comforting illusion of continued existence', while Salesa suggests that the perceived responsiveness to the present of knowledge of the past leads many indigenous scholars even today to reject Western history. $4^{6}$

The imagery contained within chants further pointed to a worldview in which time was driven forward by human rather than divine agency, and the past was open to being rewritten. 47 Indeed, the Kumulipo belonged to a class of chant called $k u$ 'auhau, a word which evokes a roadway trodden out by human feet, and its cosmogony was described as a 'founding' or a 'beginning' rather than a 'creation', placing humans, not the divine, at the forefront. $4^{8}$ Recurring

$4^{\circ}$ Fornander, Account, I, p. 19; J. F. G. Stokes, 'An evaluation of early genealogies used for Polynesian history', Journal of the Polynesian Society, 39 (1930), pp. 1-42, at p. 3 .

$4^{1}$ Malo, Hawaiian antiquities, pp. 1-2; Stokes, 'Evaluation', p. 4 .

$4^{2}$ D. Salesa, 'The Pacific in indigenous times', in D. Armitage and A. Bashford, eds., Pacific histories: ocean, land, people (Basingstoke, 2014), p. 41 .

43 Malo, Hawaiian antiquities, p. 54 .

44 Qu. Silva, Aloha betrayed, p. 93.

45 Beckwith, trans. and ed., Kumulipo, p. 9.

$4^{6}$ Kame'eleihiwa qu. in Silva, Aloha betrayed, p. 93; Salesa, 'Pacific', p. 39.

47 Silva, Aloha betrayed, p. 120.

$4^{8}$ Beckwith, trans. and ed., Kumulipo, pp. 35, 154. 
motifs in Polynesian tradition included that of the journey of a mother's firstborn child to seek recognition of a highborn father in a distant land to lay claim to high status, and that of an old line being superseded by new stock, symbolized by a cock:

Born is the cock on the back of Wakea

Ended is [the line of] the first chief of the dim past dwelling in cold uplands. 49

Both of these images demonstrate belief in the ability to reshape a genealogical past through human action in the present. Again, we thus see that strict chronology is not inevitably built into genealogy, as recognized by New Zealand anthropologist Ralph Piddington as far back as the 1950s, and also by African scholars including David Henige, who has long pointed to the importation of names into king lists as evidence of the unsuitability of using genealogy to reconstruct chronology. $5^{\circ}$

Jan Vansina shows that genealogical knowledge in many societies is preserved and recited by a select group with ritual rewards and sanctions, for instance among the Aztecs, the Incas, and the Bono-Mansu of West Africa. $5^{1}$ In Polynesia, too, the employment of skilled genealogists was imperative for chiefs, for it was through their endeavour that a successful claim to the past could be made; only in Tonga was there no such guild. $5^{2}$ Sheldon Dibble of the ABCFM noted that in Hawai'i, there had always been people whose 'special business' it was 'to preserve unimpaired the genealogy of their kings', but it seems that they also ensured the version presented was most flattering to their employer.53 Beckwith believes a 'renowned poet of Kamehameha's time was intrusted the task of weaving together family genealogies and eulogistic songs into an integrated whole', even though Kamehameha's accession was in reality characterized by fragmentation, rivalry, and bloodshed.54 Kalākaua meanwhile employed the Board of Genealogy to emphasize in the Kumulipo particular cultural images such as the heron, symbolizing the plotters against him, and Maui who, like Kalākaua, was born into the royal family through an alien alliance. 55

Effective composition and recitation of genealogies demanded wordplay, vocal technique, and memory. Stokes hypothesized that the longer and fuller

49 Ibid., pp. 3o, 96, 109; Gill, Myths, pp. 14, 88.

$5^{\circ}$ Piddington, 'Note on the validity', at p. 200; D. P. Henige, The chronology of an oral tradition: quest for a chimera (Oxford, 1974), p. 190.

$5^{1} \mathrm{~J}$. Vansina, Oral tradition: a study in historical methodology, trans. H. M. Wright (London, $1965)$, pp. $3^{1-3}$.

$5^{2}$ P.S. Herda, 'Genealogy in the Tongan construction of the past', in P. S. Herda, J. Terrell, and N. Gunson, eds., Tongan culture and history: papers from the Ist Tongan history conference held in Canberra I4-I7 January I987 (Canberra, 1990), p. 21.

53 Dibble, History, p. 17.

54 Beckwith, trans. and ed., Kumulipo, pp. 25, 28.

55 Ibid., pp. 69, 153 ; Silva, Aloha betrayed, p. 103. 
the genealogy, the greater credence it was given when employed for ceremonial purposes; only the most recent parts had to have basis in fact, but elements lying outside living memory provided an impressive compositional flourish. $5^{6}$ In order that mana remained intact, it was important that the genealogy was recited perfectly, and as such genealogists employed myriad linguistic techniques and mnemonic devices, including word association, punning, euphonic association, and cumulative repetition. 57 The past did not seem to convey legitimacy unless attached to a feat of human endeavour in the present, and the work of the genealogist was that feat.

Oral accounts were moreover bound up with bodily practice. One Hawaiian affirmed that listeners could only distinguish between multiple meanings of the same word when speech was accompanied by 'the rise of an eyebrow, an expression of the face, a tilt of the head, or a description molded with fingers' $.5^{8}$ In addition, objects were important mnemonic devices. Specifically, carved incisions present on a range of artefacts from across Polynesia (Figure 1) could assist with the recollection and recitation of genealogies. Aspects of these carvings, such as notching or the series of circular discs or spools found on flywhisks, reference multiple generations of ancestors, and objects displaying them were called upon on important ceremonial occasions. To this day, Maori orators use a carved tokotoko (staff) for emphasis during their speeches, which contain genealogical references. 59

We might consider as a point of comparison the Luba peoples of south-east Zaire, whose collective memory is bound up with a range of objects inseparable from oral transmission, and essential to the preservation of Luba identity. ${ }^{60}$ The body of the genealogist, itself laden with mnemonic symbols in its scarification and coiffure, acts as a sieve through which information is filtered, stimulating a unique interpretation. ${ }^{61}$ Although Vansina suggests that 'a verbal testimony... recorded in writing is still just as much the outcome of an oral tradition as one which has not been committed to writing', we should remain aware of how meaning might have been lost in writing down genealogies. ${ }^{62}$

From this fact, we may begin to understand exactly how problematic it is to claim to understand Polynesian conceptions of the past through sources which have been transcribed and translated. We might see implicit in McDougall's critique of Beckwith, for instance, a condemnation of the

$5^{6}$ Stokes, 'Evaluation', pp. 4-5, 7 .

57 Ibid., pp. 7-13; Beckwith, trans. and ed., Kumulipo, p. 36 .

${ }_{5}^{8}$ Qu. Gunson, 'Understanding Polynesian traditional history', p. 149.

59 Many thanks to Maia Nuku, Associate Curator for Oceanic Art, Metropolitan Museum of Art, New York.

${ }^{60} \mathrm{~J}$. Vansina, 'From memory to history: processes of Luba historical consciousness', in M. N. Roberts and A. F. Roberts, eds., Memory: Luba art and the making of history (New York, NY, 1996), pp. $12-13$.

${ }^{61}$ Ibid., pp. 41, 44 .

${ }^{62}$ Vansina, Oral tradition, p. 53 . 


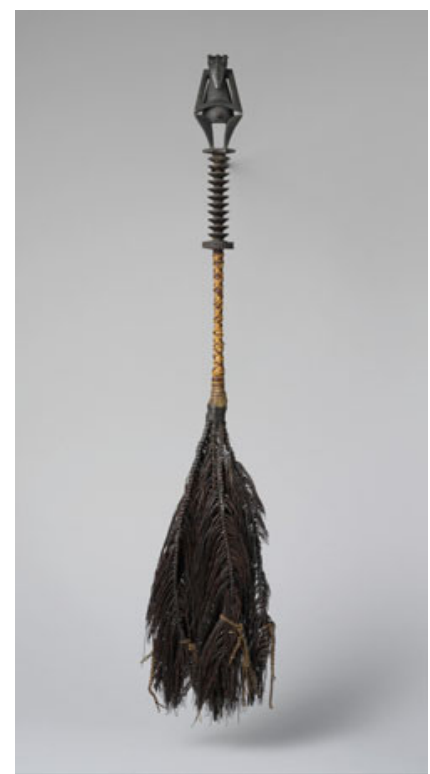

Fig. 1. Fly Whisk (Tahiri), French Polynesia, Austral Islands. The Metropolitan Museum of Art, New York, NY, the Michael C. Rockefeller Memorial Collection, Bequest of Nelson A. Rockefeller, 1979, accession number 1976•206•1487, www.metmuseum.org, Open Access for Scholarly Content, on www.metmuseum.org/about-the-met/policies-and-documents / image-resources.

attempt to translate a chant decades after it was first written down as a fundamental misunderstanding of genealogy which fails to grasp the importance of kaona and the unique relationship between composer and listener at any point. ${ }^{6}$ Nogelmeier moreover suggests that newspapers are a better source for study of the genealogical past than the English-language 'canon' because the public forum offered by newspapers, while in one sense opening up the interpretation of genealogy to a wider audience, far better replicated oral tradition by allowing chants and genealogies to be presented, to be confirmed or rejected by other contributors. ${ }^{6}$ In Nogelmeier's words, 'the extraction of any portion of that material from its context of dialogue and peer response... is problematic', in that it affirms the 'finality of print' ${ }^{6} 5$

The genealogies which reach the English-speaking scholar thus by contrast appear somewhat decontextualized, being collected from individual genealogists, rather than from multi-vocal debates. Polynesian genealogists were men of high breed, remaining close to the chiefly classes or indeed being chiefs themselves, as in the case of Mamoe and his wife, the informants of LMS

63 McDougall, 'Putting feathers on our words', p. 14.

${ }^{6}$ Nogelmeier, Mai pa'a i ka leo, pp. 81, 96, 103-4.

65 Ibid., pp. 88-9. 
missionary J. B. Stair on Samoan genealogy. ${ }^{66}$ They were recognized to hold great mana through their knowledge of the past, which in its 'purest' form was held by only a few, and which was itself hereditary - William Wyatt Gill of the LMS obtained much of his information from the Mangaian priest Tereavai, but much more material had been lost through the death in battle of Tereavai's father Tuka before it was handed down. ${ }^{67}$ Because of their high status, genealogists were often among the first converts of missionaries who clearly saw top-down conversion as the key to acceptance of Christianity in Polynesia, for instance treating King Pomare II's profession of Christianity in 1812 as a turning point for all Tahiti. ${ }^{68}$ This was not the case in Africa where marginalized members of society, for example women and young people, were often the first converts; as such, even if the idea of a specialized genealogical 'school' was not unique to Polynesia, the nature of missionaries' interaction with genealogists was more so. ${ }^{69}$

Indeed, it was in the context of conversion that missionaries often received their knowledge of Polynesian lore. One of Orsmond's key informants was a convert of high status named Mare who became a deacon of the Tahitian church.70 Gill meanwhile said that 'nothing but the reception of the new faith could have induced Tereavai to yield up to the stranger the esoteric teachings of the priestly clan'. ${ }^{71}$ The best examples again come from Hawai'i, for it was out of Dibble's history class at the Lahainaluna Mission Seminary that the most complete works of indigenous authorship on Polynesian tradition emerged. Dibble sent his ten top students to collect and record facts about the Hawaiian past, and their collective work found expression in a volume published at the Seminary in $1838.7^{2}$ Though these students remained uncredited by name in Dibble's own work, upon which they undoubtedly exercised great influence, two of them - Malo and Kamakau - went on to publish notable individual works. 73

66 Stair, Old Samoa, p. 14.

67 Gill, Myths, p. xx.

68 Davies, History, p. 153; 'To the Rev. T. Cuzens, to the deacons and to church members assembling in the King Street Chapel, Portsea, Hants. From their apparently forgotten brother in church fellowship, J. M. Orsmond, 1849', CWM/LMS/South Seas/Odds/ Miscellaneous/Box 6, Council for World Mission Archives, School of Oriental and African Studies, London (CWM Archives).

69 J. Comaroff and J. L. Comaroff, Of revelation and revolution, I: Christianity, colonialism, and consciousness in South Africa (Chicago, IL, 1991), p. 240; P. S. Landau, The realm of the word: language, gender, and Christianity in a southern African kingdom (Portsmouth, NH, 1995), pp. 86, 109; D. Maxwell, Christians and chiefs in Zimbabwe: a social history of the Hwesa people c. I87os-I99os (Edinburgh, 1999), p. 108.

$7^{\circ}$ Davies, History, p. 237; Henry, Ancient Tahiti, p. 247.

$7^{1}$ Gill, Myths, p. xx.

$7^{2}$ B. R. Finney, R. K. Johnson, M. N. Chun, and E. K. McKinzie, 'Hawaiian historians and the first Pacific history seminar', in N. Gunson, ed., The changing Pacific: essays in honour of H. E. Maude (Oxford, 1978), p. 310.

73 Ibid., pp. 311-12. 
The conversion of genealogists may in part explain how traditional imagery came to collide with that of Christianity. Beckwith believes that in more recent Hawaiian genealogies we witness a move away from ideas of organic growth towards conceptions of Kane as a single creative force akin to the Christian God, of Wakea and Papa as the definitive original pair of humans mirroring Adam and Eve, and of Kanaloa as a fallen devil-figure.74 Fraser found further evidence of this in the Samoan myth in which Tangaloa the creator looks down upon his work and exclaims 'it is good!'.75 Most prevalent is the idea of a great flood, which is so common that it must have had roots in traditional metaphor, but which became this in the Marquesas:

The Lord Ocean is a going

To pass over the whole dry land.

A respite is granted.

For seven days...

...Carry away the animals. Here.

Carry them away to the sea. Here.

$\mathrm{O}$, the long deep wood. Here. $7^{6}$

Certainly, we might explain such phenomena in terms of converted genealogists' attempts to reconcile the Bible with oral tradition; Kepelino, for example, was convinced he was recovering the 'true religion' from which Hawaiians had 'departed greatly'.77

Malo's work is instructive when considering the effects of Christianity upon genealogists. In his early life, Malo was close to the high chief Kuakini, and trained under one of Kamehameha I's favoured genealogists and chiefs, Auwae, but he then found Christ through ABCFM missionary William Richards. $7^{8}$ He completed his Hawaiian antiquities in 1839 , after his conversion. Although Malo was praised for not replicating missionary bias as much as some of his contemporaries, Nathaniel B. Emerson, translating his work at the end of the nineteenth century, still lamented his tendency to 'confound together the evil and the good, the innocent and the guilty, the harmless and the depraved in one sweeping condemnation', suggesting that he had become hypersensitive to Christian sensibilities.79 Malo also made persistent reference to 'ancient Hawaiians', even when referring to customs prevalent within his lifetime. ${ }^{80}$ The word 'ancient' was not used to refer to a specific epoch, but to create a sense of distance from pre-Christian Hawai' $i$ and to assert that transformation

74 Beckwith, trans. and ed., Kumulipo, pp. 118, 144, 154, 171 ; Henry, Ancient Tahiti, p. 307.

75 Fraser, 'Samoan story', p. 169.

$7^{6}$ Fornander, Account, I, pp. $225^{-7}$.

77 Stokes, 'Evaluation', p. 28.

$7^{8}$ Malo, Hawaiian antiquities, pp. vii, ix.

79 Finney, Johnson, Chun, and McKinzie, 'Hawaiian historians', p. 313; Malo, Hawaiian antiquities, p. viii.

8o For example Malo, Hawaiian antiquities, p. 76 . 
had occurred. At the same time, Malo showed contempt for popular interpretations of the past, which expressed themselves as legends recycling genealogical figures and motifs, and in doing so asserted his continued high social standing. ${ }^{81}$

Despite obvious cases of conversion leading to alteration of genealogies, it is wise to be cautious how much we attribute directly to missionary influence. ${ }^{82}$ Dorothy Barrère and Kenneth Emory both point out that missionaries who recorded Polynesian lore intended to gather only that which was taught before the coming of Christianity - they did not expect nor wish to see Biblical influences cropping up, as shown by LMS missionary William Ellis's scepticism when confronted with the appearance of Eve in a genealogy. ${ }^{83}$ Though the intent of figures such as Kepelino is certainly one part of the story, we might choose to emphasize instead the slow infiltration of such imagery, which had first arrived with Europeans in the late eighteenth century, as another stage in the evolutionary process of past-making. ${ }^{84} \mathrm{M}$. F. C. Bourdillon has considered a similar phenomenon among the Shona of Zimbabwe - his informant was a myth-maker who was not a member of the Catholic church, but who included several Biblical figures in his narratives. ${ }^{85}$

In any case, it was not just missionaries who ensured that islanders were familiar with Biblical imagery. In the Marquesas, for example, the beachcomber Thomas Lawson was responsible for an adulteration of tradition perpetuated by Fornander, believing the indigenous version of the flood myth to be unsatisfactory. ${ }^{86}$ More broadly speaking, this might suggest how islanders' conceptions of time were not unaffected by contacts with outsiders other than missionaries; of course, the material objects which traders, beachcombers, and explorers brought, notably guns, were often profoundly disturbing to the existing cosmological order, reshaping notions of power and warfare which were inseparable from genealogical understanding. ${ }^{87}$ At the very least, we can say that the appearance of Biblical motifs does not straightforwardly represent the sweeping aside of Polynesian tradition by missionaries, but rather further highlights the dynamic nature of genealogy.

\footnotetext{
81 Ibid., p. 237.

82 Beckwith, trans. and ed., Kumulipo, p. 168.

83 W. Ellis, Polynesian researches, during a residence of nearly six years in the South Sea islands (2 vols., London, 1829), II, pp. $3^{8-9}$.

84 D. B. Barrère, 'Revisions and adulterations in Polynesian creation myths', in G. A. Highland, R. W. Force, A. Howard, M. Kelly, and Y. H. Sinoto, eds., Polynesian culture history: essays in honor of Kenneth P. Emory (Honolulu, HI, 1967), p. 104.

85 M. F. C. Bourdillon, 'Gleaning: Shona selections from Biblical myth', in W. James and D. H. Johnson, eds., Vernacular Christianity: essays in the social anthropology of religion, presented to Godfrey Lienhardt (Oxford, 1988), pp. 123, 128-9.

86 Barrère, 'Revisions and adulterations', p. 116.

87 Thomas, Islanders, p. 22.
} 
During the first half of the nineteenth century, missionaries were better placed than any other outsiders to engage with and write about Polynesian culture, and the story they told was one of rapid and irrevocable transformation. Traditional views of the past were described as part of a culture which was fading away, but were not seen to have any tutelary value. Hiram Bingham of the ABCFM was particularly damning: 'How imperfectly...were those stupid, unlettered, unsanctified heathen tribes furnished for making out a trustworthy history of their country for ages back or even for a single generation!... We need records carefully written by men thoroughly acquainted with the people, and friendly to the truth. ${ }^{88}$ Implicit here was a perceived link between truth and the written word, which Jean Comaroff says inherently presents a linear view of time. ${ }^{89}$ In placing so much value on writing, nineteenth-century Protestant missionaries differed from early modern Spanish Catholic evangelists in the Philippines, for example, who retained ideas about the sacred resonance of the spoken word, Christ's own mode of transmission. $9^{\circ}$

References to genealogies were furthermore placed only in the context of wider-ranging works. This might be explained by the fact that early missionaries were asked to take 'the greatest care...to avoid such a Conformity to the Heathen Superstitions of the Natives as would confirm their rooted prejudices, by leading them to suppose that you give credit to their religious traditions' $.9^{1}$ Missionaries may have worried that too close an engagement with Polynesian culture at this early stage would have appeared to benefactors as though they were 'going native'. This explains why although Orsmond, Ellis, and others engaged with Polynesian accounts, we find no evidence of this in their journals, which were sent back to London for the directors' perusal.

Also manifest in missionaries' discussions of the Polynesian past during the first half of the nineteenth century was their uneasy relationship with science. Consideration of LMS missionary John Williams's seminal 1837 volume A narrative of missionary enterprises in the South Sea islands is illuminating in this respect. Williams showed an obvious concern to frame his work in terms of precision and empiricism which were increasingly of great discursive importance, though of course reminding the reader that knowledge should only be sought to 'illustrate the wisdom or goodness of the great and beneficent Creator'. $9^{2} \mathrm{He}$ set out his claim to scientific authority in examining the

${ }^{88} \mathrm{H}$. Bingham, A residence of twenty-one years in the Sandwich Islands, or the civil, religious, and political history of those islands (New York, NY, 1969), p. 18.

${ }^{89} \mathrm{~J}$. Comaroff, Body of power, spirit of resistance: the culture and history of a South African people (Chicago, IL, 1985), p. 141 .

$9^{\circ}$ V.L. Rafael, Contracting colonialism: translation and Christian conversion in Tagalog society under early Spanish rule, (Ithaca, NY, 1988), pp. 40-1.

$9^{1}$ Davies, History, p. 18.

$9^{2}$ Williams, Narrative, pp. viii, 24-5; Smith, European vision, pp. 1, 254; M. T. Bravo, 'Precision and curiosity in scientific travel: James Rennell and the Orientalist geography of 
Polynesian past, derived 'not only from an intimate knowledge of the habits of thought and modes of communication with which [the islanders] are familiar, but more especially from the circumstance of his having kept a minute record of...interviews and events'.93

Rather than engaging substantively with Polynesian genealogies, Williams treated them as asides, describing the Polynesian past primarily in terms of contemporary 'scientific' theories about race: he presented 'indubitable evidence' of the Asiatic origin of Polynesians, foreshadowing the Aryan race theory of the later nineteenth century. 94 Helen Gardner suggests that missionaries were keen to engage with this debate in the interests of proving common human origins, thus pointing to a universal 'faculty of faith', and demonstrating that the missionary enterprise was not futile. 95 The corollary of this viewpoint was the belief that Polynesians had 'degenerated' from their original knowledge of the divine. Williams called upon cosmogonic narratives only to support this notion, saying that Samoan knowledge of Tangaloa as Supreme Being was 'among the few remaining traces of the great original truths' ${ }^{6}{ }^{6}$ The form of Polynesian genealogy might have made him reflect on the many genealogies within the Bible, which in themselves superficially represented a chronology dating back to the earliest humans, though they were in fact obviously orally transmitted and inflected by tribal and literary views. 97 Instead, however, by engaging more intensively with scientific debates than with Polynesian narratives, Williams situated his Christian viewpoint alongside science and history rather than genealogy.

An influx in the second half of the nineteenth century of non-missionary observers keen to analyse Polynesian narratives served to alter the missionary relationship with science, and with Polynesian accounts. One stated aim of these analysts, including ethnologists as well as settlers who deemed themselves authorities on Polynesian culture, was to maintain the relevance of Polynesian traditions for the present, and missionaries were a particular target of their vitriol. Ultimately, however, the result of such observers' efforts was that misunderstandings, copying errors, and agendas became increasingly pervasive. $9^{8}$ Desperation to shoehorn Polynesian accounts into a historical framework led

the new imperial age $(1760-1830)$ ', in J. Elsner and J. Rubiés, eds., Voyages and visions: towards a cultural history of travel (London, 1999), p. 166; T. Fulford, D. Lee, and P. J. Kitson, Literature, science, and exploration in the Romantic era (Cambridge, 2004), p. 2.

93 Williams, Narrative, p. viii.

94 Ibid., p. $5^{\mathrm{O} 2 .}$

95 H. B. Gardner, 'The "faculty of faith": evangelical missionaries, social anthropologists, and the claim for human unity in the nineteenth century', in B. Douglas and C. Ballard, eds., Foreign bodies: Oceania and the science of race, I750-1940 (Canberra, 2008), pp. 260-1.

$9^{6}$ Williams, Narrative, pp. $54^{6-7}$.

97 M. D. Johnson, The purpose of the Biblical genealogies, with special reference to the setting of the genealogies of Jesus (Cambridge, 1969), pp. 254, 256; R. R. Wilson, Genealogy and history in the Biblical world (New Haven, CT, 1977), pp. 2-8, 199-200.

$9^{8}$ Luomala, 'Documentary research', pp. $176-7$. 
to a selective treatment of mythology, and Kamakau recognized the trend of 'foreigners who claim to know so much about our land and people, but whose knowledge is only superficial' .99

We see this most starkly in the work of Abraham Fornander, who pledged to rescue Hawaiian tradition from interfering missionaries, and from ultimate 'isolation and oblivion'. ${ }^{100}$ Like Williams, Fornander wished to offer a scientifically credible account of the Polynesian past in terms of contemporary theories about race and migration but, unlike Williams, fully incorporated Polynesian genealogies in this quest. Quoting H. H. Bancroft, Fornander claimed that 'there is not one of those stories, no matter how silly or absurd, which was not founded in fact'. ${ }^{101}$ Fornander took great pride in asserting his right to speak for the Polynesian people - he had a Hawaiian wife, thirty-four years' residence, and claimed to be 'well known, personally or by reputation, to every man within the group' - and to the scientifically minded reader described his conclusions as 'extremely probable', having taken into account 'ethnic, linguistic, and social phenomena'. ${ }^{102} \mathrm{He}$ wrote his account first with the aim of linking Polynesians to the Aryan race, the progenitors of civilization originating in South Asia, and secondly with a determination to turn genealogies into a historical narrative. ${ }^{103}$ In doing this, however, he unquestioningly accepted the presence of Biblical motifs as evidence of Aryan origins, and ended up taking mythical figures to be human. ${ }^{104}$ The irony is that, in his assumptions, he abandoned the rigours of historical scholarship which he evidently felt to be important, resorting to speculation and elision.

Others made similar arbitrary assertions about traditional accounts in an attempt to tie Polynesians to shared Aryan origins with Europeans: Emerson deemed that one myth read 'as if it had been taken straight from Aryan headquarters', while Fraser found Aryan roots for a myth of creation by Tangaloa, making comparisons with Biblical cosmogony. ${ }^{105}$ The 'evidence' could be turned to other agendas just as arbitrarily - Fornander's work was a riposte to those who asserted not Aryan, but Malay origins for Polynesians, while Fraser confusingly both gave credence to the Aryan race theory, and asserted a common origin for Polynesians and Australian Aborigines on the basis of shared mythical motifs. ${ }^{106}$ Even without referring to the framework of Aryanism, S. Percy Smith showed determination to make Maori tradition historical, despite having acknowledged that prestigious names were simply

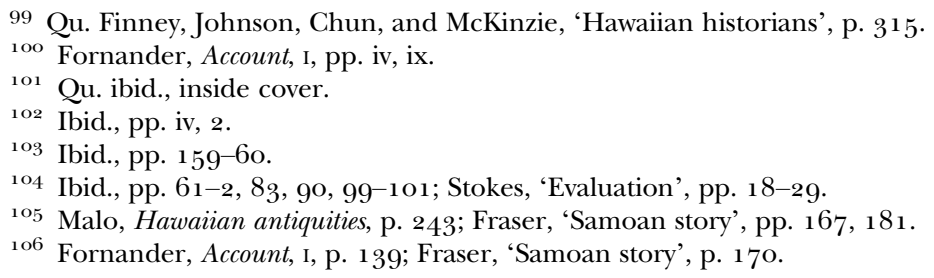


interpolated into genealogies. ${ }^{107}$ Such attempts at historicization were undermined by the fact that observers could not even agree on how long a generation was - while Fornander worked with a thirty-year generation, Smith used twenty years. ${ }^{108}$

Attempts in the second half of the nineteenth century to draw Polynesians and Europeans into the same story were, at least in part, due to the intensification of a formal colonial project. As Tony Ballantyne shows in the case of New Zealand, gathering knowledge about Polynesian tradition was an important part of state-building from the $184 \mathrm{os}$, seen as a way of avoiding subversion by sects with unknown languages and customs. ${ }^{109}$ Aryan race theory moreover justified the colonial project as the reunification of long-lost Aryan cousins the British and the Maori. ${ }^{10}$ Even where writers such as Fornander seemed opposed to colonialism, they were engaging with a scientific discussion which emerged out of political necessity.

As secular observers insisted that Polynesian versions of the past had continued relevance, however, missionaries became even more concerned with treating tradition as an artefact which had been swept away by Christianity; even prominent Wesleyan missionary and amateur scientist George Brown did not begin to engage with debates about race until he began working in Melanesia, after his time in Samoa. ${ }^{11}$ Gill, writing in 1876 , expressed his determination to avoid the comparisons made by others: 'Whilst collecting my myths, I put away from me all classical mythology, being afraid that unconsciously I might mould these Polynesian stories into similarity with those of Greece and Rome. ${ }^{112}$ Eight years later, George Turner of the LMS published his volume on Samoa, and his frontispiece signalled his intention to treat what he had collected as part of a dead culture: it depicted a Samoan woman, wearing only a loincloth in the manner which missionaries had worked so hard to change, and was captioned 'Samoan Woman in Costume of the Past'. ${ }^{113}$ Meanwhile, the very title of J. B. Stair's 1897 publication Old Samoa, or flotsam and jetsam from the Pacific Ocean evoked that he was simply recording odds and ends from a former society. He too refused to be caught up in theorizing, claiming that: 'I have not consulted other writers in my collection of data, feeling that it would be impossible to do so without being in some measure biased by the views of others. ${ }^{114}$ Gill, Turner, and Stair recorded traditional tales as a mere

107 S. P. Smith, 'The genealogy of the Pomare family of Tahiti, from the papers of the Rev.J. M. Orsmond, with notes thereon by S. Percy Smith', Journal of the Polynesian Society, 2 (1893), pp. $25^{-42,}$ at p. 30 .

${ }_{108}$ Fornander, Account, I, p. 165 ; Smith, 'Genealogy', p. 41.

109 T. Ballantyne, Orientalism and race: Aryanism in the British empire (Basingstoke, 2002), pp. 63,133 .

110 Ibid., p. 4 .

111 H. B. Gardner, Gathering for God: George Brown in Oceania (Dunedin, 2006), pp. 107, 123.

112 Gill, Myths, p. xiii.

113 Turner, Samoa, frontispiece.

114 Stair, Old Samoa, p. 15 . 
curiosity, presenting several different versions without suggesting which was 'true' or ironing out contradictions. Moreover, Gill's notebook, alongside slightly later work from Samoa by George Pratt, is the most substantial example of engagement with Polynesian accounts to be found in the LMS archives, suggesting that missionaries, in their implicit assertion that the transformation to Christianity was complete, became more confident in studying these accounts for their own sake. ${ }^{115}$

We see most clearly how different observers would do different things with a body of collected accounts in the relationship which developed between LMS missionaries Thomas Powell and George Pratt, and the ethnologist John Fraser. Powell collected Samoan accounts over twenty-five years, mainly from Tauanu'u, the official legend-keeper of Manu'a, and his nephew Fofo. He did nothing with them in his lifetime, implying his collection was for the sake of curiosity rather than scientific endeavour, but his widow sent the manuscripts on to Pratt, who set about translating them, with the patronage and help of Fraser. ${ }^{16}$ It was Fraser, however, who published the collection: the first part featured in the Journal and Proceedings of the Royal Society of New South Wales in 1890 , and the rest in a series of five articles written for the Journal of the Polynesian Society between 1896 and 1898 , after Pratt's death. In these articles, Fraser stamped his scientific authority upon the translated myths. His analysis of an origin story concerning a pair of Siamese twins commented on the medical likelihood of their birth, and concluded that if the ancestors of the Samoan and Polynesian people did come from India, they must have been familiar with such ideas as could give birth to the making of this myth' ${ }^{117}$ In another case, Fraser asserted the genuineness of a creation story with clear Biblical inflections, on the basis of his knowledge of the Samoan character: "Anyone who knows the Samoans will find it impossible to believe that such men of honour as...Fofo and Tauanu' $u$...would...recite this song as genuine when they knew it to be corrupt.' ${ }^{118} \mathrm{He}$ displayed an obsession with ascertaining the 'correct' version of any given myth, and asked the reader to trust his judgement on this matter. ${ }^{119}$

One should be careful not to dichotomize missionary collection and non-missionary theorization too much. After all, the systematic study of local cultures had not crystallized into a professional anthropological discipline at this

115 William Wyatt Gill's manuscript notebook, 1868-75, CWM/LMS/Personal/Box 1/ Miscellaneous Personal Papers, CWM Archives; 'The genealogy of Samoan kings and princes, by George Pratt, 189o', CWM/LMS/Odds/Miscellaneous/Box 3, CWM Archives.

${ }^{116} \mathrm{~J}$. Fraser, 'Some folk-songs and myths from Samoa', Journal of the Polynesian Society, 5 (1896), pp. $171-83$, at p. 171 .

117 Ibid., pp. 171-2.

118 J. Fraser, 'Folk-songs and myths from Samoa', Journal of the Polynesian Society, 6 (1897), pp. $19-36$, at p. 19 .

${ }^{119} \mathrm{~J}$. Fraser, 'Folk-songs and myths from Samoa', Journal of the Polynesian Society, 7 (1898), pp. $15^{-29}$, at p. 15 . 
stage, and all observers, missionaries as well as those who identified first and foremost as scholars for instance Fraser and Smith, were to an extent bound by the same frameworks. Most obviously, all writers still subscribed to Christian morality. Emerson, despite lamenting Malo's oversensitive condemnation of much Hawaiian tradition, spoke in hyperbolic terms about Malo's conversion: 'Though nurtured in the superstitious faith and cult of old Hawaii... when the light reached him, the old errors were dissipated with the darkness.' ${ }^{120}$ Even Fornander, despite his vigorous defence of Polynesians, subscribed to a model of degradation, contrasting the glorious Polynesian accounts of migration with their 'isolated, deteriorated, decaying' state by the eighteenth century. ${ }^{121}$

Missionaries' writings, meanwhile, were still very much grounded in scientific assumptions, even if their close engagement with Polynesian peoples allowed them to produce extremely detailed and descriptive accounts. Implicitly, they adopted a scientific viewpoint by treating Polynesian culture as something of the past: a competing theory with that of the Aryan race in the late nineteenth century was that which suggested indigenous cultures, and even people, would die out in the face of 'civilized' society. This legitimized the imposition of Christianity and colonialism not only by asserting the superiority of European and American culture, but also by alleviating guilt, as it assured that cultural and human losses were inevitable in the progression towards civilization. ${ }^{122}$ Missionaries also to an extent still actively sought scientific legitimacy; Gill's and Turner's volumes were introduced by respected scholars Friedrich Max Müller and E. B. Tylor respectively, who in each case spoke for the value of the subsequent work. ${ }^{123}$ More exceptionally, in New Zealand, CMS missionary Richard Taylor teamed up with prominent ethnologist and government official Edward Shortland and asserted Maori links to an Aryan race. ${ }^{124}$

Nonetheless, the subtle differences between the writings of outsiders operating within these broad frameworks still speak of varying ways of engaging with genealogy, informed by respective missionary and non-missionary agendas. Thus, in the second half of the nineteenth century, we see that the difficulties of dealing with Polynesian accounts of the past presented European and American observers with an epistemological challenge. The 'empirical' approach of Fornander and Fraser, focused on demonstrating validity and maintaining relevance, was set against the ethnographic missionary methodology involving the collection of customs for posterity. We still see echoes of this debate, if we accept Salesa's suggestion that there are two dominant representations of Polynesians - as part of a timeless ethnographic present, or as a people

120 Malo, Hawaiian antiquities, p. xiii.

121 Fornander, Account, II, p. 8.

${ }^{122} \mathrm{P}$. Brantlinger, Dark vanishings: discourse on the extinction of primitive races, I80o-I93o (Ithaca, NY, 2003), p. 2.

123 Gill, Myths, pp. v-xviii; Turner, Samoa, pp. ix-xii.

124 Ballantyne, Orientalism, p. 68. 
who were. ${ }^{125}$ In the long run, the missionaries' approach appears less foolish, but it was motivated by a desire to relegate forcibly an entire cosmology to the dustbin of history; as Gunson, Vansina, and Phyllis Herda all point out, we must not deny the possibility that oral traditions might contain some clues to history. ${ }^{126}$ The reality was that both approaches represented agendas which obfuscated the true dynamism of Polynesian genealogy.

\section{V}

The theme running throughout this article is that of the broadly creative, rather than appropriative, nature of the cultural encounter between Polynesian islanders and missionaries during the nineteenth century, elucidated by a focus on the role which ideas about the past played within this encounter. We do not see the collision of two monolithic traditions in which a Western epistemology inevitably emerged triumphant. Instead, political, cultural, and religious agendas defined the ways in which all agents engaged with the Polynesian past, and as such multiple synthesized understandings emerged.

Of course, on the one hand, we see a new mythological lexicon drawn from Christianity employed in diverse ways in Polynesian genealogies. This development appears to be in keeping with existing notions of the dynamic relationship between the past and the needs of the present, and it probably helped islanders come to terms with the novelties and anxieties of engagement with Christianity and colonialism. At the same time, and most pertinently, we witness the fragmentation of Western 'historical' thought, which was not only confounded by the dynamism of Polynesian tradition, but was also governed by the needs of the present. Missionaries swept aside Polynesian tradition, collecting genealogical tales as artefacts but appealing primarily to 'science' to frame their view of the past, as they sought to affirm the profoundly modern and progressive vision of their enterprise. Non-missionary observers meanwhile tried to write genealogies into historical narratives, often in order to keep in step with theories of race that underpinned the colonial project, and as such sometimes both directly contradicted missionaries and ignored the mechanics of Polynesian traditional accounts.

Genealogy continued to be a site of negotiation and contestation, and was brought decisively into legal debates over land ownership in New Zealand in the twentieth century. ${ }^{127}$ Following the establishment of the Waitangi tribunal

125 Salesa, 'Pacific', p. 39 .

${ }^{126}$ N. Gunson, 'Tongan historiography: shamanic views of time and history', in Herda, Terrell, and Gunson, eds., Tongan culture, pp. 18-19; Vansina, Oral tradition, pp. 1-2, 15, 30$1,39,48,65,67-75,76,81,102,140$; Herda, 'Genealogy', pp. $24-5$.

${ }_{127}$ M. D. Dominy, 'New Zealand's Waitangi tribunal: cultural politics of an anthropology of the High Country', Anthropology Today, 6 (1990), pp. 11-15, at p. 13; A. Mikaere, N. Tomas, and K. Johnston, 'Treaty of Waitangi and Maori land law', New Zealand Law Review (Part III, 2003), pp. $447^{-84}$, at p. $4^{60}$. 
in 1975 , tribes were able to bring land claims against the government, and the scope was extended in 1985 to cover historic claims dating back to the 1840 treaty of Waitangi. Tribes such as the Ngai Tahu of the South Island were able to achieve legal recognition and substantial settlements by the end of the century. ${ }^{128}$ While it would be wrong to suggest that nineteenth-century Maori would have recognized the ways in which their oral traditions were marshalled through this new framework, we see again how Polynesian genealogy and islanders' commitment to the ancestral past proved remarkably adaptable to changing circumstances. Because of this adaptability, outsiders' attempts to appropriate these narratives for their own histories have failed.

128 T. M. Tau, 'Epilogue', in T. M. Tau and A. Anderson, eds., Ngai Tahu: a migration history (Wellington, 2008), pp. 201-3. 